\title{
THUG LIFE: Drill music as a periscope into urban violence in the consumer age
}

\section{Adam Lynes, Craig Kelly and Emma Kelly}

\section{Introduction}

The historic relationship between street gangs and hip-hop music dates back to the birth of the genre (Hagedorn, 2008). Numerous hip-hop artists have had, or continue to have, a close association with prominent street gangs, and a smaller number of artists have acknowledged they were once members of a street gang (see Kubrin, 2005). A complex and multifaceted relationship exists between street gangs and hip-hop music and it is important to avoid reductive accounts of this relationship. However, we must also be brave enough to acknowledge that a relationship does indeed exist. In this paper we argue that it is now time for the social sciences to engage in a concerted intellectual attempt to untangle and shed light upon this relationship, clarifying its various features and identify the fundamental causes that led to the relationship's formation. To that end, we draw upon some hitherto underused and often misunderstood concepts and frameworks with a view to illuminating a complex cultural dynamic often judged too politically and intellectually sensitive to justify critical attention.

Violent crime in London rose significantly in 2018. Media attention was drawn to an emerging subgenre of hip-hop music called 'drill' (Fatsis, 2019). The media's perennial search for novelty and, when addressing social problems, its propensity to identify only the most simplistic proximal causes, led a number of outlets to suggest that drill music was driving the city's young people towards deadly violence (see Knight, 2018; Cohen, 2018; and Nsubuga, 2018). Cressida Dick, the head of the Metropolitan Police, petitioned Youtube to remove content featuring, or uploaded by, a number of drill artists. Dick's intervention resulted in the removal of around thirty videos, and some drill artists were blocked altogether (see Waterson, 2018). To a popular readership, all of this seemed to lend credence to the suggestion that drill music was causing violence, or at least that certain drill music artists used the music genre to insight violent crime. 
Shortly afterwards, two drill music artists were sentenced to nine months in prison, suspended for two years, for breaching an injunction by performing drill music and posting videos that incited and encouraged violence against rival gang members' (DJ News, 2019). Of course, such simplistic causal accounts tell us very little about the complex relationship between music, culture, everyday life and the contexts in which violence arises and is enacted (Ilan, 2020; Fatsis, 2018 and 2019). They tell us nothing about why this medium is chosen by specific urban populations as a means of communicating threats, status claims, mockery and retorts, or how the content of such music relates to the subjective experience of everyday life in marginalised urban neighbourhoods (ibid.). In constructing such simplistic accounts, media commentators overlook the possibility that the forms of braggadocio and direct threats we see in drill videos are not particular to this music genre. Clearly, such performances exist as a perennial feature of urban social reality (see for example, Anderson, 2000; Winlow, 2001; Winlow and Hall, 2009; Bougois, 2010; Mullins, 2013; Ellis, 2015). Threats to other gangs or specific individuals certainly didn't magically appear as a feature of everyday social reality as drill music began to take shape. It is imperative we dig deeper.

Of course, the simplistic causal account that we have outlined above is problematic not simply because it is simplistic, and not simply because it ignores the actual causes of violent crime and the contextual realities that frame its enactment. Media stories that position drill music as a cause of urban violence also, with varying degrees of subtly, tend to reaffirm the view that young urban black men - and the forms of culture that appear tied to this population - constitute a threat to the civic mainstream. These stories, structured in relation to the assumption that urban black men are more likely to be criminal and violent, appear to have fed into the vague police cultures that sustain racialised stop and search practices in the capital (Delsol and Shiner, 2015; Flacks, 2017). Virk (2018) reports that the Metropolitan Police have in fact used stop and search powers to disrupt the filming of drill music videos. The actual causes of violence are incredibly complex (see for example Winlow, 2015; Ellis, 2015; Ellis et al., 2017) and deserve to be treated as such. If our goal is to understand the causes of rising levels of urban violence, 
we must accept that there are no easy answers. Below we begin to untangle the relationship between drill and violence. The first step is to establish some reasonably functional contextual parameters.

\section{Drill: Context and History}

If we are to construct a useful account of the relationship between drill music and violence, the first step should be to place this specific musical subgenre in the context of contemporary consumer culture (see Yousman, 2003; Hayward, 2004; Perry, 2004; Hall et al., 2008; Hunter, 2011). Consumerism intrudes upon the internal life of the subject in ways that are only now beginning to be understood (see Hall et al., 2008; Winlow and Hall, 2016). As many theorists and researchers have found, consumerism erodes collective identities and projects (see for example Baudrillard, 2007), inspires a particular kind of possessive individualism (see for example Bauman, 2000), and foments envy and a general disregard for the well-being of others (see for example Zizek, 2002). It dissolves traditional forms of value and seeks to establish the accumulation of money and the sign-value of consumerism as the sole measure of a good life. Consumerism, as the hegemonic 'meaning system' of contemporary popular culture, therefore provides the background against which contemporary urban life plays out. We can quite easily identify processes of commodification in all music genres (see Adorno, 2016), but it seems reasonable to position hip-hop - a musical form that developed during the consumer age and evolved in parallel with consumer culture - as the archetypal musical genre of twenty-first century consumerism. We should also note that British hip-hop has a long attracted the critical attention from the police (Bramwell, 2015). Bakkali (2019) suggests that road culture is a UK-specific cultural formation that draws upon Black Atlantic popular culture (Gilroy, 1987). Drill is tightly connected to road culture (Ilan, 2020). As Bakkali (2019) claims, road culture should not be defined purely in terms of race and ethnicity (see also Gunter and Watt, 2008). Drill music offers young people a means of expression, a means of mediating often complex social relationships and a means of achieving a degree of status relative to the social field. Money and consumerism mix with threats, mockery and claims to violent potential. But that is not all there is. As we will see, drill is also a specific urban construct rooted in the experience of class and oppression (see Galtung, 1969 and Fatsis, 2018). 
Drill appears to have been developed by Chief Keef and numerous other artists on the South Side of Chicago in 2011. It grew rapidly and began to develop a degree of mainstream popularity. Following the death of rapper Lil Jojo in a drive-by shooting in 2012, linked to a dispute with the man widely believed to be the creator of drill, Chief Keef (Harkness, 2013), drill began to be regularly connected to the perennial problem of inner-city violence. Chicago was and is a city with very high levels of urban violence (Irwin-Rogers and Pinkney; 2017; Pinkney and Robinson-Edwards 2018), but in the last ten years or so there has been a tendency to connect Chicago's longstanding violence problem with what is a relatively new form of music. Harkness (2013), claims that the sheer number of gangs and gang members in the city are a key part of the problem, and he also notes that many of these gangs contain active or peripheral members who make drill music. Of course, even if we accept that the presence and proliferation of gangs in Chicago shape violence rates, we must also note that gangs cannot in and of themselves be considered to be the fundamental cause of murderous violence. Gangs, and more importantly the immediate urban milieu that shapes gang life, may form part of a causal chain that leads to violence, but gangs are also an effect of a deeper lying cause (see Hall and Winlow, 2015).

Drill is known for its hyper-masculine, overtly violent content (Ilan, 2020). Drill artists, in videos and such like, often make explicit reference to unsolved murders, and direct threats to other artists are also very common (Irwin-Rogers and Pinkney, 2017) though as Ilan (2020) affirms, to take all such content literally ignores the complex realities. By mid-2015, drill had proliferated across the globe and London began to see the emergence of a fledgling drill scene. Whilst various subgenres of hip hop, most notably Grime (Bramwell, 2015), have been part of mainstream British culture for some time, the drill scene in London and Birmingham quickly gained notoriety. The murders of drill artists such as Showkey (Offord, 2016), Tuggzy (Booth, 2017), Skeng (Morrison and Mitchell, 2017), Mdot (BBC, 2016) and Incognito (BBC, 2018) clearly played a role in establishing in the popular imagination a firm relationship between drill and violence. The arrests of high-profile drill artists also drew attention and appeared to further the mystique of the scene. Nino and KK, artists from South East London connected to the B-Side Gang, were convicted for the murder of a record producer connected to the Splash Crew 
(Sullivan, 2017). M-Trap 0, from South London, was convicted for the murder of Jermaine Goupall, at the time only fifteen-years-old (Badshah, 2018). Baby R, from Croydon, was convicted of conspiracy to commit murder and other charges (Truelove, 2017). Reekz mb was arrested for attempted murder (Ballinger, 2018). Most recently, Unknown T and another defendant were charged with violent disorder and murder for the death of Steven Narvaez-Jara on New Years Day 2018. The pattern appeared clear.

\section{Methodology}

This paper seeks to move beyond the tired stereotypes perpetuated by the popular media, though due to the lack of academic focus upon the subject media sources must be relied upon. However, we have no intention of simply applying moral panic theory to this developing cultural trend. Moral panic theory is, we argue, ill-suited to getting to grips with the radically transformed culture in which we live (see Horsley, 2017, for a thorough and convincing deconstruction of the place of moral panic theory in contemporary criminology). There has been no mass 'panic' about drill music. A significant proportion of the UK population probably haven't even heard of drill music, let alone formed firm ideas about its purportedly regrettable outcomes. This is not to say that this musical form and its associated cultures haven't attracted negative headlines and draconian police action (Fatsis, 2019). The institutions of the state and the corporate media, it seems, no longer needs to carry the population along with scare stories to justify the criminalisation of particular urban populations. Nor has there been any great attempt to suggest that drill music is immoral, save for the direct suggestion that it inspires or glorifies violence. In these secular times, in which traditional concepts of morality appear to have fallen into generalised accounts of 'values', moral stories in the popular press are few and far between. Even those stories in the press that have addressed drill music and the involvement of some drill music artists in violence have not been positioned on the front page, and this fact also tells us an additional story about descent of traditional morality: The killing of young, working-class, urban black men is now simply a filler story, a sad indictment of our times, but certainly not something to get animated about. To get to grips with what drill music tells us about road culture and urban life we need to draw upon intellectual resources that are better suited explaining contemporary social and cultural phenomena. We start with 
a descriptive account of the long and complex relationship between violence, street gangs and hip-hop music. We focus on 50 Cent, Biggie Smalls and Tupac Shakur. We will then draw upon these resources to develop a critical account of urban violence in the consumer age.

\section{Conceptualising Violent Realities}

There is a long history of academic and popular interest in the interplay between violence and popular cultural trends (Kelly et al.,2018). Since the 1960s in particular, various genres of music have been cited by the media as the driving force for various forms of criminal or deviant behaviour (Tucker, 2002). For the most part, the state and various institutions of the corporate power structure appear to have subscribed to what we might call a right-realist perspective. However, and more contemporaneously, critical scholars have acknowledged that social media usage can be an aggravating factor in contemporary forms of urban violence (Irwin-Rogers and Pinkney, 2017). Pinkney and Robinson-Edwards (2018) claim that the violent lyrics often utilised in drill, and more broadly throughout hip-hop, are examples of what Surette (2015) calls performance crime. Put simply, the street scripts the screen and the screen scripts the street (see Hayward and Young, 2004).

Academics keen to establish a causal link between media forms and violent crime have tended to utilise the deeply flawed psychology evidence gathered by Bandura et al., $(1961,1963)$. One of the central problems of utilising Bandura's general framework is that it is blind to a whole host of contributing factors that are external to Bandura's rather basic focus upon the subjective consumption of media symbolism. We hear nothing of the broader context of socialisation and experience. We hear nothing about narratives of morality, about the cultural contexts inhabited by thinking and feeling subjects, or about those internal processes that sift, sort, appraise and apply forms of cultural symbolism. As Ray (2011: 6) notes, the social context for 'both the performance and understanding of violence is of central importance'. According to Bufacchi (2005) there are two ways of conceptualising violence. First, there is the often narrow 'minimalist conception' that focuses upon bodily harm through physical force (Glasser, 1998). Stanko's (2001: 316) oft-cited definition of violence - violence as 'any form of 
behaviour by an individual that intentionally threatens to or does cause physical, sexual or psychological harm to others or themselves' - fits firmly in this category. However, whilst Stanko's body of work around violence has added much needed nuance around the gendered perspectives of violence it can be argued it fails to account for a rounded notion of the breadth of violence in both the epistemological and ontological sense. Scholars as far back as ancient Greece have recognised the complexity of such notions. Much like Freud's tripartite understanding of the human condition; Homer, Plato and subsequently the German idealist Hegel have recognised the Nous (Reason), Thumos (spiritedness) and Epithumia (desires) were in an incessant battle with one another. The Thumos was central to this in relation to understanding violence is underpinned with the importance of honour, prestige and accomplishment at the fore. It is from this perspective of the yearning for recognition as an individual that underpin the emotions which underprop violence and offer a more complete conceptualisation of the subject. From this understanding we can recognise the need for a 'comprehensive conception' of violence. Comprehensive conceptions of violence attempt to capture forms of violence and subsequent harms not recognised by the definition offered by Stanko. This latter approach can therefore attempt to capture forms of harm that may be significant but are not necessarily physical. Galtung's (1969) concept of 'structural violence' is notable here. In Galtung's conceptualisation, job insecurity, unemployment and the removal of welfare entitlements can all be categorised as expressions of structural violence. For example, some individuals and communities can suffer greatly as a result of the political beliefs and ideological commitments of others. Žižek (2008) has also written important works that seek to clarify the meaning of 'structural violence'. In a characteristic dialectical inversion, Žižek draws our attention not to those forms of violence that disrupt what would otherwise be civilised normality, but to the actual constitution and reproduction of civilised normality as such. For Žižek (2008), structural violence is the form of violence that needs to take place to reproduce our sense of normality. It is the form of violence implicit in our current way of life. It is a violence that is so ubiquitous, so all-encompassing, that it barely registers. For example, we may judge the ongoing destruction of the natural environment to be an expression of structural violence (Bonds, 2015; 2016). We may also consider the harms of sweatshop labour around the world to be expressions of structural violence. Both of these forms of violence, in the present ideological context, essentially need to take place so that we can continue on as consuming 
societies. Structural violence should thus be considered to provide a zero point against which we can judge other forms of violence (which, in Žižek's tripartite schema, are subjective violence and symbolic violence). Subjective violence - violence committed by a clearly identifiable subject, like a gang or an individual - and symbolic violence - a violence of symbols, signs, words and narratives - both, in essence, disrupt the 'normality' established by the grinding everyday nature of structural violence. Žižek's (2008) goal is to broaden out our conception of violence. He wants us to look away from spectacular forms of disruptive violence - like a shooting or a stabbing on the streets of South London - and consider those forms of violence that shape our experience of everyday life. As Žižek suggests, it is only when we consider these underlying, everyday forms of structural violence that we can begin to move close to the fundamental truths that shape the spectacular forms of subjective violence that tend to grab the headlines and draw our attention as social scientists.

The following examination is underpinned by the Žižekian perspective on violence. Focusing on the realities of drill music and the immediate contexts that gave rise to it allows us to catch sight of the grinding structural violence that underpins our present way of life.

\section{Competition and Clashes within Hip Hop Culture: A Brief Overview}

Since the beginning of hip hop New York in the 1970's, machismo has been intrinsic to the art form. Initially DJ's utilised emcees to promote their performance prowess to the crowds but the emcees soon began promoting themselves within these braggadocios moments. During this seminal period, content largely revolved around the lyrical dexterity of the artist and their ability to motivate the crowd. However, when Kool Moe Dee humiliated the jovial emcee Busy Bee over a perceived slight in the late 1980 's, the notion of rap disses and 'beef' was born, and soon became an integral part of hip hop culture (Nguyen, 2014). The first 'disses' on recorded media came soon after in the form of the now infamous 'Roxanne' tapes, solidifying within the culture the commercial potential of successfully humiliating a perceived opponent. 
As rap music became increasingly profitable to both artists and record companies, the politics of consumer culture soon began to influence the battles between emcees. Due to the increase in popularity emcees soon emerged from the west coast, including NWA, Snoop Dogg and other well-known Californian artists moving the scene away from New York, generally regarded as the 'birth place' of hip hop (Stolworthy, 2017). These artist used raw, honest and hyperbolic lyrics to reflect the chaos of the lived experience of street life in Los Angeles, a city struggling with gang warfare and a crack epidemic which framed the habitus (Bourdieu 2002) in which these artists came from. This furthered the scripts discussed by Surette (2005).

The New York based hip hop record industry, media outlets and, arguably most importantly, radio stations regarded the upcoming west coast 'G-funk' gangster rap as a threat to the hegemony of east coast rap and attempted to subjugate the new sound (Westhoff, 2016). The overtly violent lyrics of the west coast rappers, reflective of their 'street' perspective, soon developed into diss tracks which were exchanged between artists from each coast. The nature of battle rapping quickly morphed, soon to include territorial, gang related references. Death Row Records, headed by notorious Blood gang member Marion Suge Knight, was founded alongside the genre's transitional period, consolidating existent underlying relations between gang lifestyles, rap music and now mainstream consumer culture Following his release from prison, Tupac Shakur signed a record deal with Death Row Records, a decision that became the catalyst to the most notorious and profitable rap 'beef' in history.

Whilst early pioneers had emphasised socio-political consciousness as well as jovial, carnivalesque rhymes, consumerism had always featured. As the early nineties progressed, the most commercially successful rappers moved from aspiring to possess attainable consumer products such as a pair of Adidas trainers (Patton, 2009) to more expensive items such as cars and private planes (Coward, 2015), realistically unobtainable to the majority, at least by conventional means. As the industry grew, the possessions flaunted by the artists became increasingly extravagant objects of desire. In essence the street culture of hip hop had grown from and subsequently went through a hyperbolic transformation which was increasingly out of touch with the audience that consumed it (Ferrell et al., 2015). It is important to note this transitionary period occurred coinciding with the onset and legacy of Reagan's 
neo-liberal politics. Such transitions effectively denigrated the distinctive counterculture of modernity that Gilroy (1987) had observed within the culture.

\section{Tupac Shakur \& Biggie Smalls- Profitable Street Capital}

Tupac Shakur (16/06/1971 - 13/09/1996) was an American rapper and actor who came to embody the 1990s gangsta-rap aesthetic (Westhoff, 2016). Tupac's early career established him as a hard-edged social commentator with songs such as "Brenda's Got a Baby" documenting an underage mother's fall into destitution, and "Soulja's Story" causing media and political controversy as it told of "blasting" a police officer and "droppin' the cop". It was subsequently heavily criticised by the then U.S. Vice President Dan Quayle, who stated that "there is absolutely no reason for a record like this to be published...it has no place in our society" (Drummond, 1992). His third album was written while in prison on sexual abuse charges .Disparately on the gold-certified single "Keep Ya Head Up," he empathised with "my sisters on the welfare," encouraging them to "please don't cry, dry your eyes, never let up." Tupac's fourth album was his debut at Death Row records. It was an unrepentant celebration of the thug lifestyle and often characterised as 'gangsta-funk hedonism' (Marriott, 2018). Within this we can garner the perspective of Ilan (2020) who draws attention to the lyrics in drill often not being as literal as one my first suspect, but a complex and multifaceted reflection of street culture. The album eventually became diamond certified. On September 7 1996, whilst in Las Vegas with Suge Knight. A fight broke out between a Crip gang and Tupac after they had watched a Mike Tyson bout at the MGM Grand hotel. Knight and members of his entourage, who were affiliated with the rival Bloods became involved. Later, as a car that Tupac was sharing with Knight stopped at a red light, the rapper was shot. Tupac later died in hospital from his injuries.

Biggie Smalls (21/05/1972 - 09/03/1997) was a hip-hop artist said to have single-handedly reinvented East Coast hip hop (Brown, 2004). He began selling drugs at age 12 in Brooklyn. Biggie received a five-year probationary sentence in 1989 after being arrested on weapons-possession charges (Scott, 2001). Two years later he was charged with dealing cocaine in North Carolina and spent nine months in jail (Scott, 2001). Upon his release from prison he made a demo tape under the pseudonym Biggie 
Smalls. His debut album, Ready to Die, was released on Bad Boy Records in September 1994. On the album's less mainstream singles, Biggie did not attempt to hide his street capital credentials, utilising it to enhance his consumer capital. This is most prominently displayed within the song "Gimme the Loot" in which Biggie and his younger self discuss the ways in which they plan to rob members of the public and others involved in organised crime (Hatchman, 2015). Whilst working on music for his debut album, Biggie Smalls met Tupac Shakur. Their encounter took place at a party held by an L.A. drug dealer (Westhoff, 2016). After this meeting Tupac mentored Biggie, with Biggie even asking at one point if Tupac would become his manager.

\section{Coast to Coast Profit}

This relationship changed on November 29, 1994 when Tupac was shot five times during a robbery in a recording-studio lobby in New York (Ladd and Brennan, 2017). Shakur believed Biggie and his label boss had orchestrated the attack (Ladd and Brennan, 2017). This was reinforced when two months later, Biggie's single "Big Poppa," was released which included the song "Who Shot Ya?". Tupac interpreted this as Biggie provoking him (Ladd and Brennan, 2017), and released a response in the form of "Hit 'Em Up," the following year, on which he gloated to having slept with Biggie's wife. In August 1995, upon the release of Tupac from prison, Knight attended an annual awards show at Madison Square Garden's Paramount Theatre. Death Row spent $\$ 100,000$ on its opening-act stage show, which included life-size jail cell replicas- again using street capital as a marketing tool. Suge took to the stage to accept his label's award for best soundtrack and pointed to Sean "Puffy" Combs, the head of Bad Boy, Biggie Smalls' label. Alluding to Puffy's tendency to insert himself in his performers' works, Suge said:

"Any artist out there wanna be an artist, and wanna stay a star, and don't have to worry about the executive producer trying to be all in the videos, all on the records, dancing-come to Death Row" (Kantrowitz, 2016).

The ongoing rivalry was thus thrust into the media spotlight (which the media labelled the 'East coast/ West coast beef') and led many to believe that Biggie was behind Tupac's death shortly after. Reflecting on Tupac's death, Biggie acknowledged the transformative power the fall out caused with entire 'coasts' 
picking a side in the context of the violent rhetoric. Specifically, he noted his regret in the two failing to reconcile and set an example to the fans and entourages who became embroiled and who were heavily influenced by the record companies.

Biggie was murdered in the early hours of March 9, 1997 after leaving a party in Los Angeles. Whilst waiting at a red light in his SUV, a vehicle pulled alongside and a gunman opened fire (Kading, 2011). On the $25^{\text {th }}$ of March, 1997, Biggie's second album Life after Death was released posthumously, going on to sell over five million copies (Caulfield, 2018). The early demise of the artists emphasised the notion that violence can be extremely lucrative to the record industry. The legacy of the artists, both in terms of record sales, literary publications, films and television shows charting their careers and the 'coastal feud' they were embroiled in reinforced this commercial potential.

\section{Violent Lyrical Blueprints for Capital}

Following the deaths of Tupac and Biggie the hip hop genre went through a somewhat transitory period. Whilst songs directly insulting other artists still proliferated and garnered much attention within popular media (for example, Nas and Jay-Z), the violent rhetoric decreased, with artists mindful of the devastating effects of violent street culture encroaching upon mainstream music culture could bring. Although the popularity of the genre was increasing, the socio-political context that had been prevalent since the early origins of the hip hop genre (Kitwana, 2005) were relegated from mainstream release and coverage, subjugating such artists to 'underground' popularity as the lyrical focus of mainstream artists became increasingly sexualised and materialistic.

By the turn of the millennium the genre had, at least in main stream culture (Ilan, 2012), become a commodity of commercialised consumer culture with sexualised overtones with plentiful tales of drug lords and 'ghetto folk-lore'. However, around the same time, artist 50 Cent's debut single How to Rob, opening with a tribute to Tupac and Biggie, followed the blueprint of the 'Roxanne' tapes, with a four minute graphic account of how he intended to rob significant artists throughout the music industry. The resurgence of hip hop's violent subject matter had begun. The progress made since the deaths of Tupac and Biggie began to flounder. 50 Cent subsequently accelerated to superstar status whilst the subject of 
many controversial episodes, having been shot multiple times and stabbed (50 Cent, 2007). With many explicit references to his supposed gangster persona and successful consumer life style, his first major album, Get Rich or Die Trying in 2003 was released whilst engaging in 'beef' with artists on the Murder Inc. record label. The music industry was once again central to violent street conflicts with the album signifying a return to the era prior to the passing of the aforementioned artists. The album contained a slew of monologues re-enacting fictional drive-by shootings against his perceived opponents which eventually led to various violent altercations between the opposing factions. Unlike the preceding case study though, both artists survived this particular 'beef'.

Understanding the evolution of hip hop culture is critical to our understanding of the subgenre of drill and its violent lyrics. Many of the artists within this emerging scene did not live through the development of the wider genre. Their experience of the culture is signposted by fruitful careers being built on the foundation of lyrical expression of violence directly targeting other artists, especially when we consider the history of the garage and grime sub-genres in the United Kingdom (Ilan, 2012). That the younger generation are structurally blocked en-masse from attaining the consumer success of established artists by legitimate means, does not negate the desire to attain such goals. The rise of social media has enabled young aspiring artists to reach wider audiences without the need to engage with the 'gatekeepers' of previous generations such as record labels and radio stations. In the most basic sense, the rap 'beefs' abjectly synonymous with gang culture in the hip hop sphere have become the blueprint to successful music careers for drill artists.

\section{A Periscope into Consumer Capitalism and Inter-Personal Violence}

It is clear that the catalytic relationship between drill and rising violent crime is fraught with doubtful viability (Ilan, 2020). As Kubrin (2005) states violence is far more complex that the discursive language as a form of expression utilised in the genre. By examining drill and the case studies presented we aim to establish and enable criminological investigation to specifically develop knowledge of gang life in the United Kingdom which as Harding (2014) asserts, has until now overwhelmingly ignored socioeconomic factors. Harding (2014) highlights that Wacquant (2008) proposes that social and economic marginality leads to 'hyper-ghettoisation'. From this standpoint we propose drill is acting as a periscope 
into the chaotic gang orientated habitus (Bourdieu 2002) of some artists. The entrepreneurial culture often seen within the lower socio-economic echelons of society (Winlow, 2001), aided by the rise of social media use (Irwin-Rogers and Pinkney, 2017) and the scripts (Hayward and Young, 2004) set by American hip hop artists has provided a platform for drill artists to bring to the fore caricatures of the lived realities of economically marginalised youths in austerity Britain (Ellis, 2019) subjected to justice system rife with racial inequality (Hall et al., 1978 and Fatsis, 2018) .

Ultra-realism is built upon an original account of the subject as it interacts with the socio-economic milieu (Hall and Winlow, 2015). Ultra-realists have attempted to push beyond mere proximal causes to identify the fundamental causes of negativistic phenomena that exist at the core of our social and economic system. Ultra-realists have curtly dismissed the social, cultural and criminological literature associated with the cultural turn and encouraged criminologists to accept that our arrival in a hyperconsumerised Anthropocene era necessitates new ideas and deep thinking about the foundations of our present way of life. Ellis et al., (2017) claim that violence is 'often connected to a sense of loss and humiliation that is gendered and culturally affirmed in a way that reproduces a physically aggressive form of competitive individualism in which others are seen as substitutes for the original assailant'. In their detailed study of violent men, Ellis et al., (2017) have this to say of their respondents:

\footnotetext{
'Where other men bow their heads and walk away, our respondents see themselves stepping forward to meet challenges head-on. Where other men dream of responding violently to threats and insults, our respondents actually live the dream and impose their will upon all who question their supremacy. Where other men live lives of quiet despondency, trapped in dysfunctional relationships and in jobs they hate, our respondents imagine themselves as titans of a free market in which any determined individual willing to do what is necessary can be a winner' (Ellis et al., 2017).
}

Hall (2012) and Hall and Winlow (2015), perhaps the most influential ultra-realists working today, have constructed a number of concepts that can assist us untangling the relationship between violence and drill. Hall's (2012) theory of the pseudo-pacification process is immensely detailed, but his basic claim 
is that the massive reduction in physical violence associated with the historical shift from the middle ages to the modern age should not be read as the triumph of civilisation over barbarism. Rather, the huge fall in physical violence involved a concomitant rise in symbolic violence. Actual physical violence needed to be curtailed in order that the early capitalist economy could grow. Trust in the rule of law needed to me fomented. People needed to believe that business deals would be upheld and that they would not be robbed as they transported their goods to market. However, violence did not disappear. Rather it was forced into the symbolic dimension, where its energy could be harnessed and used to drive forward the economy. The law restricted physical violence, but in the symbolic dimension we were encouraged to be aggressively self-interested in the battle for our material wellbeing and social significance. This was not a civilising process, as Elias (1994) had claimed, but a pseudo-pacification process. The contemporary consumer economy is, as many theorists have noted, animated by envy and social competition (see Hall et al., 2008). We may believe that we have overcome violence, but symbolic violence lies at the very core of contemporary culture. The great oligarchs of the contemporary period do not need to hire private armies or strike breakers to solidity their control. They can cause irreparable harm to entire communities by signing a contract or pressing a button on a keyboard.

Hall (2011) does acknowledge that falling murder and interpersonal violence rates in the classical industrial capitalist period did indicate 'limited success'. However, due to a series of economic crises and a push for more neo-liberal agendas this pacification process would witness a breakdown. Combined with a push for a de-regulated economy alongside 'consumerism's encouragement of the return of competitive individualism' (ibid), and the deterioration of the 'economic and social interdependencies that had built up during the classical capitalist era' (ibid), Hall asserts that increasingly antagonistic foreign policies and violent state action in 'strike-breaking and maintaining public order in the USA further justified violence as an instrument in satisfying desires' (pg. 83).

Tough masculine cultures that were cultivated for industrial, social control and military functions in the classical capitalist era did not need much convincing or permission, and rates of murder, violent crime and petty interpersonal violence spiked up alarmingly in the mid-1980s 
in the USA and Britain in the chaotic, impoverished spaces thrown up by the shift from productivism to consumerism (Hall, 2007: 83).

This breakdown in the pacification process was subsequently tied to the decline in community values, and the 'most selfish, predatory, reactionary and short-termist elements ascended to the top and glorified by the media, beg[inning] to influence the general cultures in the USA and Britain' (pg. 83). Through this personal 'emancipation' to strive towards individual success and increased encouragement of consumption, the civilising process was, Hall argues, no longer necessary in an age of 'globalised flexible accumulation and competition between permanently uprooted individuals' (pg. 76). As a result of this change in the political economy one of the more contemporary and critical criminological questions 'concerns the possible return of interpersonal violence as a routine aspect of everyday life' (pg. 77). Specifically, despite the often referred to 'dark figure' of unrecorded violence 'renders statistical pictures of non-lethal violence problematic and unreliable' (pg. 77), there is an agreement amongst many criminologists that there has been an increase in the rates of inter-personal violence in both the UK and USA (ibid).

In attempting to explain this rise in inter-personal violence, it is important to consider the significance of special liberty - a consequence of capitalism that has, according to Hall and Wilson (2014), stripped away many of the pre-capitalist, collectivist ideals and in its stead created an environment in which the right to freely express one's motivations and yearnings is continually exerted. This breakdown in the pacification process has created the 'dark side' of liberal individualism, a sociopathic 'anti-ethos that consists of a sense of entitlement felt by an individual who will risk harm to others to further his own instrumental or expressive interests' (Hall \& Winlow, 2015; see also Hall, 2012). Writing in this tradition, Winlow has also suggested that:

The individual is therefore as free as the external control system allows him to be to act with impunity, free to rob, plunder and destroy without ever acknowledging the harms their activities visit upon others (Winlow, 2014: 175). 
This form of special liberty is not limited to the structural elite class, and this breakdown in the pseudo pacification process and the rise of the neo-liberal political economy has resulted in this form of liberty existing within the 'general cultural current' (Hall, 2015, pg. 129). Individuals from all echelons of society have the permission and the inclination to inflict harm on others - 'to simply get things done in order that the competitive logic of business can be served' (ibid). This mind-set - shaped and encouraged by the contemporary political economy - reverberates throughout the entire social structure, from corporate boardrooms to ghettoes. Hall states that:

To the subject of special liberty, who regards himself as a miniaturised sovereign state, the everyday 'other' individual is a sublimated variant of homo sacer, a worthless unit not necessarily to be killed - although in extreme cases this does happen - but to be exploited with impunity in order to serve the logic of the market and the enrichment of the master (Hall, 2015: 129).

The machismo that has been intrinsic to hip hop culture from its early conception has amplified to its current form. Overwhelmingly driven by the introduction of the genre as a cultural commodity (Hayward, 2004), this was magnified by the media and record labels in a bid to garner higher profit. Whilst the skilful lyrical braggadocio began as a harmless game of lyrical chess, such events began to reference violence against 'opponents' more often alongside the rise of neo-liberalism,. We propose this is an example of the degradation of pseudo-pacification which has been encapsulated in elements of road life (Bakkali, 2019) and thus drill.

Often coming from the most marginalised facets of society, hip-hop artists increasingly focussed upon the pursuit of success within consumer culture. The competitive individualism discussed by Ellis et al., (2017) is displayed vividly, with rappers increasingly utilising aggressive lyrical content (and on occasion aggressive physical manifestations of such content) to instrumentally ensure they can become the titans of a free market and 'win'.

This paper proposes that the beefs of Tupac Shakur, Biggie Smalls and 50 Cent epitomise special liberty. Therefore, special liberty is the crux of the relationship between hip hop and gang activity. As hip hop 
became mainstream and consequentially more profitable, rappers invariably exercised special liberty. Not only did the aim of 'diss' tracks cease to be playful exercises, the artists, emboldened by the record executives and media, specifically aimed to end careers and ultimately lives, with such actions resulting in the deaths of prominent artists as discussed earlier in this piece. By record companies letting artists release songs referencing not only violent threats, but in the case of Tupac's song Hit Em Up, explicit references to sleeping with his opponent's partner, both the industry and the artist displayed their perceived special liberty. A catalogue of examples are seen within the career of 50 Cent whom went as far as finding a rivals (secret) child and his mother, taking them out for dinner, and then posting the images on social media furthering this proposition. Examples of special liberty within drill culture are plentiful. As Ilan (2020) notes examples of drill artists openly goading whilst stood in their rivals postcode are abundant. During research for this paper videos were found showing a drill artist being forced to eat a house brick as retaliation for disrespectful lyrics he had uploaded to Youtube previously.

The drill artists the media have focussed upon are of a time and culture that is disproportionately affected by knife crime and such acts are perceived as routine and normalised. Simultaneously, this generation are living through a time where politics have transformed into a form of commodification, where witty quips, referred to as memes, are spread across the same social media and offer the same perceived opportunity to claw back meaning in their lives as a successful drill song. We argue this absence of real politics and debate - in turn disavowing the political systems that create their trauma can help provide a better understanding of the physical traumas perpetrated in their own areas. Essentially, rather than making the rise in knife crime attributable to drill music, it would be better suited to begin by viewing drill music as intertwined as a signifier of deep structural issues within the lives of disenfranchised youths (Galtung,1969) who are relentlessly subjected to the inherent violence of the neo-liberal epoch (Zizek,2008). To perceive otherwise, as the Metropolitan Police evidently have, would be as Ilan (2020) describes- street illiterate. Further evidence of this turn to commodification ramped up by competitive individualism at the hands of neo-liberalism can be found during a historical glance over the music of Tupac. His status initially materialised from his political messages and focus on empowerment and revolutionary lyrical content. However, within the time he joined death row 
records, a change in direction is evident. What was previously described as lyrics of empowerment for Bame communities and women shifted into contradictory content fuelled by importance of commodities and symbolisation - especially in relation to women. Importantly, this was also the period in which the 'East Coast vs West Coast beef' gained traction, displaying again the rising influence of the neo-liberal epoch in the context of special liberty and eventually providing a blue print for the attainment of success, which acted as a script for future generations of marginalised youths (Surette, 2015).

\section{Conclusion}

With reference to the work of Surette (2015), and acknowledging that hip hop is from the beginning a product of street culture and has long had intricate ties with both socioeconomic deprivation and gang lifestyles, it is viable to perceive hip hop as a looking glass into road life (Bakkali, 2019; Ilan, 2012). Whilst we emphasise that the lives and careers of hip hop artists are not to blame for a rise in violence, they are proposed as a fascinating demonstration of the detrimental effects of consumer culture and neoliberal progression. The lyrical content, 'blue print' and stark demonstrations of special liberty within popular culture has in essence scripted (Surette, 2015) the habitus (Bourdieu, 2002) of young gang members in the United Kingdom, just as the gang culture has scripted the lyrical content of Drill artists. The lyrical content of some artists, including references to unsolved murders and other acts of extreme gang related violence serve as exemplifiers of special liberty being actioned (Tudor, 2018; Winlow, 2014) in conjunction with consumer culture.

Further afield, in the Chicago drill scene this is also evident, with artists emboldened via the sense of special liberty to the point of live streaming drive-by shootings (Pinkney and Robinson-Edwards 2018). The expressive forms of inter-personal violence within marginalised communities are being wrongly articulated by the media and police service alike (Ilan, 2020). Such instances are reflective of symbolic violence brought to the fore with the structural violence (Galtung, 1969) exacerbated yet hidden within a capitalistic consumer culture (Hall et al., 2008). Drill artists from marginalised communities are on occasion involved in such violence engrained within road culture (Bakkali, 2019). However, to utilise the ghetto cultural expression (Ilan, 2012) to further the criminalisation of such notions is myopic and 
seeks to further perpetuate the marginalisation of such groups thus furthering the disavow of the objective violence Žižek discusses (2008). Ilan (2012) discusses the dilution of street cultural tropes by the mainstream music industry, though in the discussion of drill and the blueprint put forth by Tupac and Biggie, drill has resisted such dilution thus allowing the media and government to further the disavow of harms the neo-liberal epoch has brought upon the youths lived reality. When Tupac Shakur inscribed the acronym 'THUG LIFE' across his abdomen, the phrase it professed 'The Hate You Give Little Infants Fucks Everybody' was perhaps before it's time. The internal debate Shakur had around the true nature of violence transcended those posed within his lyrics. It is within this context we can begin to unravel the complexities of street culture, drill music and its relationship with violence.

\section{References}

50 Cent (2007). 50 x 50: 50 Cent in His Own Words. London: Simon \& Schuster UK.

Adorno, T. (2016) Philosophy of Modern Music, London: Bloomsbury

Anderson, E. (2000). Code of the Street, New York: Norton

Badshah, N. (2018). 'Three jailed for life for stabbing teenager to death in south London', [online] the Guardian. Available at: https://www.theguardian.com/uk-news/2018/feb/15/three-jailed-stabbingteenager-south-london-jermaine-goupall [Accessed 2 Oct. 2018].

Bakkali, Y. (2019) 'Dying to Live: Youth Violence and the Munpain', Sociological Review [early view] pp. $1-6$.

Ballinger, C. (2018). 'Gang jailed after forensics link them to same gun in shootings', [online] Croydon Advertiser. Available at: https://www.croydonadvertiser.co.uk/news/local-news/gang-jailed-afterforensics-team-1069845 [Accessed 2 Oct. 2018].

Bandura, A., Ross, D., \& Ross, S. A. (1961). 'Transmission of aggression through imitation of aggressive models', Journal of Abnormal and Social Psychology, 63, 575-582. 
Bandura, A., Ross, D., \& Ross, S. A. (1963). 'Imitation of film-mediated aggressive models', Journal of Abnormal and Social Psychology, 66, 3-11.

Barkan, S. and Bryjak, G. (2014). Myths and realities of crime justice: what every American should know. London: Jones \& Bartlett.

Baudrillard, J. (2007) In the Shadow of the Silent Majorities, London: Semiotext

Bauman, Z. (2000) The Individualized Society, Oxford: Polity

BBC News. (2018). 'Rapper cleared of murder dies in stabbing', [online] Available at: https://www.bbc.co.uk/news/uk-england-london-45039590 [Accessed 2 Oct. 2018].

BBC News. (2016). 'Teens guilty of killing rapper over bike', [online] Available at: https://www.bbc.co.uk/news/uk-england-london-38239962 [Accessed 2 Oct. 2018].

Bonds, E. (2015). 'Challenging climate change's new "security threat" status', Peace Review: A Journal of Social Justice, 27, 209-216.

Bonds, E. (2016) 'Upending Climate Violence Research: Fossil Fuel Corporations and the Structural Violence of Climate Change', Human Ecology Review, 22, (1): 1- 22.

Booth, J. (2017). 'More details revealed about Broad Green murder victim Akeem “Tuggzy” Moore', [online] Croydon Advertiser. Available at: https://www.croydonadvertiser.co.uk/news/croydonnews/more-details-revealed-broad-green-438855 [Accessed 2 Oct. 2018].

Bourdieu P (2002). 'Habitus'. In: Hillier J and Rooksby E (eds) Habitus: A Sense of Place, pp. 27-34. Burlington, VT: Ashgate.

Bourgois, P. (2010). In search of respect. Cambridge: Cambridge University Press.

Ladd, R., \& Brennan, T. (2017). Once Upon A Time in Compton: From Gangsta Rap to Gang Wars... The Murders of Tupac \& Biggie. New York: Brown Girls Publishing.

Bramwell, R. (2015). UK Hip-hop, Grime and the City: The Aesthetics and Ethics of London's Rap Scenes, London: Routledge. 
Brown, J. (2004). Ready to Die: The Story of Biggie Smalls--Notorious B.I.G.: Fast Money, Puff Daddy, Faith and Life After Death. London: Amber Communications Group, Inc.

Bufacchi, V. (2005). ‘Two Concepts of Violence', Political Studies Association, Vol. 3: 193-204.

Bulman, M. (2018). 'Councils brace for biggest government cuts since 2010 despite 'unprecedented' pressures', [online] The Independent. Available at: https://www.independent.co.uk/news/uk/homenews/england-council-budget-cuts-government-austerity-social-services-essential-care-safetya8559486.html [Accessed 3 Oct. 2018].

Caulfield, K. (2018). 'The Notorious B.I.G. Scores Fifth Million-Selling Album', [online] Billboard. Available at: https://www.billboard.com/articles/columns/chart-beat/8100012/the-notorious-bigfifth-million-selling-album [Accessed 5 Oct. 2018].

Chen, M. J., Miller, B. A., Grube, J. W., \& Waiters, E. D. (2006). Music, substance use, and aggression. Journal of Studies on Alcohol and Drugs, Vol. 67: pp. 373-381.

Clarkson, W. (2003). Gangsters. London: John Blake.

Clarkson, W. (2008). Gangs of Britain - The Gripping True Stories of the Faces Who Run Britain's Organised Crime. New York: John Blake Publishing.

Cohen, D. (2018). 'Special Evening Standard investigation into bloodshed on the capital's streets', [online] Evening Standard. Available at: https://www.standard.co.uk/news/crime/violent-londonmy-uncle-was-gunned-down-when-i-was-4-so-i-grew-up-the-little-big-man-a3889036.html [Accessed 2 Oct. 2018].

Coward, K. (2015). 'When Hip-Hop First Went Corporate', [online] the Atlantic, 21st April. Available at: https://www.theatlantic.com/business/archive/2015/04/breaking-ad-when-hip-hop-first-wentcorporate/390930/ [Accessed 2 Oct. 2018].

Delsol, R. and Shiner, M. (2015). Stop and search. Basingstoke: Palgrave Macmillan.

Derrida, J. (2002). 'Force of Law: The Mystical Foundation of Authority'. In G. Anidjar (Ed.) Acts of 
Religion (pp. 228-298). New York, NY: Routledge.

DJ News (2019). 'Two Rappers Sentenced after Breaching Injunction by Performing Drill Music', [online]. Available at: https://djmag.com/news/two-rappers-sentenced-after-breaching-injunctionperforming-drill-music [Accessed 25 Jan. 19].

Dodd, V. (2018). 'Police cuts hit London harder than other parts of UK, says Sadiq Khan', the Guardian [online] Available at: https://www.theguardian.com/uk-news/2018/jun/26/police-cuts-hit-londonharder-than-anywhere-else-in-uk-sadiq-khan [Accessed 3 Oct. 2018].

Drummond, B. (1992). 'THE 1992 CAMPAIGN: The Campaign Trail; On Quayle's List: a Rapper and a Record Company', The New York Times [online] available at: https://www.nytimes.com/1992/09/23/us/1992-campaign-campaign-trail-quayle-s-list-rapperrecord-company.html [Accessed 5th Oct. 2018].

Durham, A., Elrod, H. and Kinkade, P. (1995). 'Images of crime and justice: Murder and the "true crime" genre', Journal of Criminal Justice, Vol. 23, No. 2: pp.143-152.

Eisenhardt, K. (1989). 'Building Theories from Case Study Research'. The Academy of Management Review, Vol. 14, No.4: p.532.

Elias, N. (1994) The Civilizing Process. Oxford: Blackwell, 1994

Ellis, A. (2015). Men, Masculinities and Violence: An Ethnographic Study. [ebook] Routledge. Available at: https://ebookcentral.proquest.com/lib/bcu/reader.action?docID=4054448\&query= [Accessed 3 Oct. 2018].

Ellis, A. (2019) A De-Civilizing Reversal or System Normal? Rising Lethal Violence in Post-Recession Austerity United Kingdom, The British Journal of Criminology. 59 (4), 862-878.

Ellis, A., Winlow, S., \& Hall, S. (2017). "'Throughout my life I have people walk all over me": trauma in the lives of violent men', The Sociological Review, Vol. 65, No. 4: pp. 699 - 713. 
Fatsis, L. (2018), 'Grime: Criminal Subculture or Public Counterculture? A Critical Investigation into the Criminalization of Black Musical Subcultures in the UK', Crime, Media, Culture, doi: $10.1177 / 1741659018784111$.

Fatsis, L. (2019), 'Policing the Beats: The Criminalisation of UK Drill and Grime Music by the London Metropolitan Police’ The Sociological Review, doi: 10.1177/0038026119842480.

Farrell, J., Hayward, K., \& Young, J. (2015). Cultural Criminology. London: Sage.

Felson, R.B. (2009). 'Violence, crime and violent crime', International Journal of Conflict and Violence, Vol. 3, No. 1: pp. 23-39.

Flacks, S. (2017). 'The stop and search of minors: A ‘vital police tool'?’ [online] Journals.sagepub.com. Available at: http://journals.sagepub.com/doi/abs/10.1177/1748895817720485 [Accessed 3 Oct. 2018].

Gadd, D. and Jefferson, T. (2007). Psychosocial criminology. Los Angeles: SAGE.

Galtung, J. (1969). 'Violence, peace and peace research', Journal of Peace Research, Vol. 6, No. 3: $167-91$.

Gilroy, P. (1987). There Ain't No Black in the Union Jack. London: Routledge

Glasser, M. (1998). 'On violence: A preliminary communication', The International Journal of Psychoanalysis, Vol. 79, No. 5: pp. 887-902.

Gunter, A., \& Watt, P. (2009). 'Grafting, going to college and working on road: Youth transitions and cultures in an East London neighbourhood', Journal of Youth Studies, Vol. 12, pp. 515 - 529.

Hagedorn, J. (2008). A world of gangs. Minneapolis: University of Minnesota Press.

Hall, S., Critcher, C., Jefferson, T., Clarke, J., and Roberts, B. (1978), Policing the Crisis: Mugging, the State and Law and Order. Macmillan International Higher Education.

Hall, S., Winlow, S. and Ancrum, C. (2008). Criminal Identities Consumer Culture. Hoboken: Taylor and Francis. 
Hall, S. (2007). 'The Emergence and Breakdown of the Pseudo-Pacification Process', in Watson. K. (ed.) Assaulting the Past: Violence and Civilization in Historical Context. Newcastle upon Tyne: Cambridge Scholars Press.

Hall, S. (2012). Theorizing Crime and Deviance: a new perspective. London: Sage.

Hall, S. (2015). 'Harm, special liberty and pseudo-pacification', in D. Crewe \& R. Lippens (eds) What is Criminology About?: Philosophical Reflections. London: Routledge.

Hall S and Wilson D (2014). 'New foundations: Pseudo-pacification and special liberty as potential cornerstones for a multi-level theory of homicide and serial murder', European Journal of Criminology, Vol. 11: pp. 635-655.

Hall, S. \& Winlow, S. (2015) Revitalizing Criminological Theory: Towards a new Ultra-Realism. London: Routledge.

Harding, S. (2014). The Street Casino: Survival in violent Street Gangs. Bristol: Policy Press.

Harkness, G. (2013). Chicago hustle and flow. Minneapolis: University of Minnesota Press.

Hatchman, J. (2015). 'The Notorious BIG', the Guardian [online]. Available at: https://www.theguardian.com/music/musicblog/2015/dec/16/the-notorious-big-biggie-smalls-10of-the-best [Accessed 5 Oct 2018].

Hayward, K. (2004). City limits. London: Routledge-Cavendish.

Hayward, K., \& Young, J. (2004). 'Cultural Criminology: Some Notes on the Script', Theoretical Criminology, Vol. 8, No. 3: pp. $259-273$.

Horsley, M. (2015). The dark side of prosperity. Farnham: Ashgate.

Horsley, M. (2017). Forget 'Moral Panics'. Journal of Theoretical and Philosophical Criminology, 9(2), 84-98. 
Hunter, M. (2011). 'Shake it, baby, shake it: Consumption and the new gender relation in hip-hop'. Sociological Perspectives, 54, 1: 15-36.

Ilan, J. (2012) 'The industry's the new road': Crime, commodification and street cultural tropes in UK urban music. Crime, Media, Culture: An International Journal. 8(1), 39-55

Ilan, J. (2015) Understanding Street Culture: Poverty, Crime, Youth and Cool. Basingstoke, UK: Macmillan.

Ilan, J. (2020) Digital Street Culture Decoded: Why Criminalizing Drill Music is Street Illiterate and Counterproductive. British Journal of Criminology. [Online].Available at: https://doi.org/10.1093/bjc/azz086 [Accessed 17 Jan. 2020].

Irwin-Rogers, K. and Pinkney, C. (2017). 'Social Media as a Catalyst and Trigger for Youth Violence - Catch22', Catch22 [online]. Available at: https://www.catch-22.org.uk/social-media-as-a-catalystand-trigger-for-youth-violence/ [Accessed 2 Oct. 2018].

Kading, G. (2011). Murder Rap: The Untold Story of the Biggie Smalls \& Tupac Shakur Murder Investigations by the Detective Who Solved Both Cases. New York: One Time Publishing LLC.

Kantrowitz, L. (2016) 'How Tupac and Biggie Went from Friends to Deadly Rivals', Vice [online]. Available at: https://www.vice.com/en_uk/article/gqkqz3/tupac-biggie-friends-to-foes [Accessed 5 Oct. 2018].

Kelly, C., Lynes, A., Hoffin, K. (2018). 'Next-Gen Deviance: from School Shootings to Simplicity?!' BSC Blog [online] Available at: https://thebscblog.wordpress.com/2018/06/18/next-gen-deviancefrom-school-shootings-to-simplicity/ [Accessed 8 Oct. 2018].

Kitwana, B. (2005). Why White Kids Love Hip Hop: Wankstas, Wiggers, Wannabes and the new reality of race in America. New York, NY: Basic Civitas Books.

Knight, S. (2018). 'The Soundtrack to London's Murders', The New Yorker [online]. Available at: https://www.newyorker.com/news/letter-from-the-uk/the-soundtrack-to-londons-murders [Accessed 2 Oct. 2018]. 
Kubrin, C. (2005). 'Gangstas, Thugs and Huslas: Identity and the code of the street in rap music', Social Problems, Vol. 52: pp. $360-378$.

Ladd, R and Brennan, T. (2017) Once Upon a Time in Compton. United States: Brown Girls Publishing LLC

Marriott, R. (1997). 'All That Glitters,' in Tupac Amaru Shakur 1971-1996. Vibe Magazine (121). New York: Three Rivers Press.

Marriott, R. (2018). 'The Best Tupac Songs', Complex [online]. Available at: https://www.complex.com/music/the-best-tupac-songs/ [Accessed 20 Nov. 2018].

McKenzie, L. (2015). Getting by. Bristol: Policy Press.

McQuillar, T. L. (2010). Tupac Shakur: The Life and Times of an American Icon: The Biography. New York: Da Capo Press.

Morrison, S. and Mitchell, J. (2017). 'Man charged after father-of-two stabbed to death during fight', Evening Standard [online]. Available at: https://www.standard.co.uk/news/crime/harlesdenmurder-arrest-after-fatheroftwo-stabbed-to-death-during-fight-outside-barber-shop-a3534636.html [Accessed 2 Oct. 2018].

Mullins, C. (2013) Holding Your Square, Cullompton: Willan

Nguyen, H. (2014). 'Hip-Hop Gem: The Kool Moe Dee vs. Busy Bee Battle Revolutionised Rapping', Independent Grind [online]. Available at: https://www.stopthebreaks.com/gems/kool-moe-deebusy-bee-battle/ [Accessed 8 Oct. 2018].

Nsubuga, J. (2018). 'Aggressive' drill rap videos fuelling gang violence in London, claims community leader', Metro News. [online] Available at: https://metro.co.uk/2018/04/05/aggressive-drill-rapvideos-fuelling-gang-violence-london-claims-community-leader-7443375/ [Accessed 2 Oct. 2018]. 
NYA. (2014). 'Cuts watch: policy update on local authority cuts to youth services', - NYA. [online]. Available at: https://nya.org.uk/2014/12/cuts-watch-policy-update-local-authority-cuts-youthservices/ [Accessed 3 Oct. 2018].

Offord, J. (2016). 'Murder investigation launched after teenage rapper stabbed to death in Peckham', International Business Times UK [online]. Available at: https://www.ibtimes.co.uk/murderinvestigation-launched-after-teenage-rapper-stabbed-death-peckham-1574685 [Accessed 2 Oct. 2018].

Patton, E. O. (2009). Under the Influence: Tracing the Hip-Hop Generation's Impact on Brands, Sports, and Pop Culture. Ithaca, New York: Paramount Market Publishing, Inc.

Patton, D., Eschmann, R. and Butler, D. (2013). 'Internet banging: New trends in social media, gang violence, masculinity and hip hop', Computers in Human Behaviour, 29(5), pp.A54-A59.

Perry, I. (2004). Prophets of the hood: Politics and poetics in hip hop, London: Duke University Press.

Pinkney, C. and Robinson-Edwards, S. (2018). 'Gangs, music and the mediatisation of crime: expressions, violations and validations', Safer Communities, Vol. 17, No. 2: pp.103-118.

Pyatak E., Muccitelli L. (2011). Rap music as resistive occupation: Constructions of Black American identity and culture for performers and their audiences. Journal of Occupational Science, Vol.18: pp. 48-61.

Ray, L. (2011). Violence and Society. London: sage.

Rowley, J. (2002). 'Using case studies in research', Management Research News, Vol. 25, No. 1: pp.1627.

Sandberg, S., Tutenges, S., \& Copes, H. (2015). 'Stories of violence: a Narrative Criminological Study of Ambiguity', The British Journal of Criminology, Vol. 55, No. 6: pp. 1168 - 1186.

Scott, C. (2001). Murder of Biggie Smalls. New York: Gardners Books. 
Sprankle, E., L., End, C., M., Bretz, M, N. (2012). 'Sexually Degrading Music Videos and Lyrics Their Effects on Males' Aggression and Endorsement of Rape Myths and Sexual Stereotypes', Journal of Media Psychology, Vol. 24, pp. 31-39.

Stanko, E. A. (2001). 'The Day to Count: Reflections on a Methodology to Raise Awareness about the Impact of Domestic Violence in the UK', Criminology \& Criminal Justice, Vol. 1, No. 2. pp. 215226.

Stolworthy, J. (2017). 'History of Hip Hop: How did this underground movement begin and when did it hit the mainstream?', The Independent [online]. Available at: https://www.independent.co.uk/artsentertainment/music/news/history-of-hip-hop-music-new-york-dj-kool-herc-google-doodle-clivecindy-campbell-a7887501.html [Accessed 10 Oct. 2018].

Sullivan, T. (2017) 'Youtube rapper caged: Two YouTube rap killers sentenced to life in jail for the murder of 21-year-old Dean Pascal-Modeste', The Sun [online]: Available at: https://www.thesun.co.uk/news/5032913/youtube-rappers-sentenced-murder-of-dean-pascalmodeste/

Surette, R. (2015). 'Performance crime and justice', Current Issues in Criminal Justice, Vol. 27, No. 2, Nov 2015: pp. 195-216.

Thompson, T. (2005). Gangs. London: Hodder and Stoughton.

Thompson, T. (2008). Reefer Men. London: Hodder.

Truelove, S. (2017). ' 4 men convicted after shotgun and bullets found at Croydon home', [online] Croydon Advertiser. Available at: https://www.croydonadvertiser.co.uk/news/croydon-news/fourmen-found-guilty-conspiracy-866698 [Accessed 2 Oct. 2018].

Tucker, B. (2002). "Tell Tchaikovsky the News": Postmodernism, Popular Culture, and the Emergence of Rock 'N' Roll', Black Music Research Journal, Vol. 22: p.23. 
Tudor, K. (2018). 'Toxic Sovereignty', Journal of Extreme Anthropology, Vol. 2, No. 2: pp. 7 - 21.

Virk, K. (2018). 'Drill music video stopped by armed police', BBC News [online]. Available at: https://www.bbc.co.uk/news/newsbeat-44982560 [Accessed 3 Oct. 2018].

Wacquant, L. (2008). Urban Outcasts: A Comparative Sociology of Advanced Marginality. Cambridge, MA: Polity Press.

Waterson, J. (2018). 'YouTube deletes 30 music videos after Met link with gang violence', the Guardian [online]. Available at: https://www.theguardian.com/uk-news/2018/may/29/youtubedeletes-30-music-videos-after-met-link-with-gang-violence [Accessed 1 Oct. 2018]

Watts, E.K. (1997). 'an Exploration of Spectacular Consumption', Communication Studies. Vol. 48: pp. $42-58$.

Westhoff, B. (2016). Original Gangstas: Tupac Shakur, Dr. Dre, Eazy-E, Ice Cube, and the Birth of West Coast Rap. London: Hatchett Books.

Wingood, G., M., Diclemente, R., J., Bernhardt, J., M., Harrington, K., Davies, S., L., Robillard, A., Hook, E., W. (2003). 'A prospective study of exposure to rap music videos and African American female adolescents', health. Am. J. Publ. Hlth, Vol. 93: pp. 437-43.

Winlow, S. (2001). Badfellas: Crime, Traditional \& New Masculinities. UK: Berg.

Winlow, S. and Hall, S. (2009). 'Retaliate First: Memory, Humiliation and Male Violence', Crime, Media, Culture, 5, 3: 285-304.

Winlow, S. (2014). 'Some thoughts on Steve Hall's Theorizing Crime and Deviance - a new perspective', Journal of Theoretical and Philosophical Criminology, Vol. 6, No. 2, pp. 168 - 193.

Winlow, S. (2015) 'Trauma, guilt and the unconscious: some theoretical notes on violent subjectivity', Sociological Review, 62, Supplement S2: $32-49$

Winlow, S. and Hall, S. (2016) 'Criminology and Consumerism', in P. Carlen and L. Ayres Franca (eds) Alternative Criminologies, London: Routledge 
Wrathall, M. (2005). How to Read Heidegger. London: Granta Books.

Yousman, B. (2003). 'Blackophilia and blackophobia: White youth, the consumption of rap music, and white supremacy', Communication Theory, 13, 4: 366-391.

Zizek, S. (2002) Welcome to the Desert of the Real, London: Verso

Zizek, S. (2008). Violence. London: Profile Books. 